\title{
People-Centered Strategy in Sustainable Management: Construct Development of Professional Worker Performance in Society 5.0
}

\author{
Narendra Prataksita ${ }^{1}$, Sasmoko $^{2}$, Elidjen $^{3}$, Agustinus Bandur $^{4}$ \\ \{narendra.prataksita@gmail.com ${ }^{1}$, sasmoko@binus.edu ${ }^{2}$, elidjen@binus.edu ${ }^{3}$, abandur@binus.edu ${ }^{4}$ \} \\ Bina Nusantara University, Jakarta, Indonesia ${ }^{1234}$
}

\begin{abstract}
In the last few decades, research related to organizational sustainability has received a lot of attention from both academics and business. One of the main reason is because organizational sustainability is seen as important aspect for long-term organizational success. However, the social or human dimensions are considered rarely discussed compared to the environmental and economic dimensions of organizational sustainability. Moving towards Society 5.0 which aims to provide a human-centered world that is sustainable, vibrant and livable, making the human dimension of organizational sustainability even more important. This study employs a literature review with theory synthesis approach and integrating between Drucker's knowledge-worker's productivity theory, Atkinson's Flexible Firm and Dawis's theory of work adjustment (PEC Theory) to propose that optimal utilization of professional worker could increase work engagement and potentially contribute to organizational and environmental sustainability in Society 5.0. Furthermore, this study provides an integrated perspective and examine the antecedents and consequences of Professional Worker Performance in Society 5.0.
\end{abstract}

Keywords: knowledge worker, professional worker, society 5.0, work engagement

\section{Introduction}

In the last few decades, research related to organizational sustainability has gained a lot of attention both from academics and business. Organizational sustainability seen as important aspect not only for organizational performance [1-4] but also for long-term organizational success [1,5,6]. A sustainable organization is believed to have the ability to achieve the triple bottom line that consist of economic, environmental, and social performance, simultaneously and sustainably [6,7]. 
However, the social or human dimensions are considered rarely discussed in organizational sustainability compared to the environmental and economic dimensions. Previous study suggest that the human dimension is associated to aspect that generates social wellness, improving employee quality of life and well-being (i.e., job satisfaction and employee engagement) in organizations [1,5,7-10]. Furthermore, there are growing intention to realizing "Society 5.0" [11-14]. In Society 5.0 human-technology interaction from Industry 4.0 will be utilized to provide a human-centered world that is sustainable, vibrant and livable [15-17].

Society 5.0 is also meant to bring economic benefits for individuals at the required time and in just the right amount whether it us the necessary goods or services [12]. Those economic benefit achieved by dynamic engagement of all citizens in the new economy as well as society by utilization of new technologies from Industry 4.0 [13]. Moreover, to successfully implement Society 5.0, Government of Japan plan to transform all citizens so all citizen able to think independently and create new values by combining various items while working with others. This transformation is Government of Japan method to securing professional human resources. These objectives can be accomplished by providing education to foster creativity, improving IT literacy as well as promotion and literacy of lifelong education [13].

The objectives of citizen transformation and professional human resources term in Society 5.0 closely similar with Ekstedt [18-20] definition of professional worker. Furthermore, Surawski [21] concludes professional worker as the closest group that share the same key characteristics with knowledge workers and defined in detail in an international standard of occupational classification.

The aim of this article is to develop a conceptual study concerning the management of professional worker and ways of increasing their contribution to organizational and environmental sustainability in Society 5.0. The problem for discussion is as follows: how can professional worker contribute to organizational and environmental sustainability in Society 5.0? This conceptual paper aims primarily at developing a set of constructs, regarding factors likely to promote professional worker contribution in Society 5.0.

\section{Methodology}

This paper aims to develop a conceptual framework through literature review with theory synthesis approach. Theory synthesis approach seeks to attain conceptual integration throughout various theories or literature streams 
[22]. Integration enables researchers to see a concept or phenomenon in a new perspective by transforming earlier results as well as theory into a novel higher-order perspective that links phenomena that previously seems unconnected or incompatible pieces in a novel way [23].

Literature search process includes the selected sources, (1) ABI/INFORM Collection ;)2( Advanced Technologies\& Aerospace Collection ; (3) Coronavirus Research Database ;and )4 (Publicly Available Content Database , that accessed through Proquest $) \mathrm{http} / /$ :www.proquest.com .(/In this conceptual framework development there are two focus of the study as follow, 1( knowledge worker orprofessional worker as the best proxy group; and (2) social or human dimension of sustainability such as social wellness, wellbeing and quality of life. Therefore, the combinations of the keywords and boolean operator to filter the data is ("knowledge worker" OR "professional worker") AND ("social wellness" OR "well-being" OR "quality of life").

The literature searching and filtering consist of three consecutive procedures. The first is "Studies Found" that indicate the number of publication found based on the combinations of the keywords. After that, we filtering based on the paper title and abstract. Publication which the titles and abstracts match the research objectives will be keep as "Candidate Studies". The last part of filter involving the examination of "Candidate Studies". All of the candidate papers will be read thoroughly. Candidate papers that relevant to answer the research objectives will be defined as "Selected Studies". Moreover, some exclusion criteria are applied to clarify the validity of literature, which are:

1. The paper that published before 2010 (only publication in the last 10 year included in this study);

2. Non peer reviewed scholarly journals,

3. Journals that the full manuscript are not available in ProQuest,

4. Duplicate paper.

The result of literature search process resulted in 312 studies found based on boolean search. From 312 studies found, there are 132 papers becomes candidate studies based on papers title and abstract related to research objective. After further study, there are 41 papers which relevant in this research. 


\section{Theoretical Framework}

In this study, there are three major question with each question related to distinctive theoretical framework. First question is "What is professional worker?". Some researchers have certain definition of professional worker [18-20]. Surawksi [21] also concludes professionals as the closest group for researching knowledge workers. Although in term of knowledge creation, knowledge worker is highly related to knowledge-based view [24,25] and personal knowledge [26,27]. The traits of knowledge worker itself that highly suitable with human resource in Society 5.0 is more relevant to Drucker's knowledge-worker's productivity theory [28-30].

Second question is "How professional worker can contribute to organizational and environmental sustainability?". The answer lies in how firm and organization utilize professional worker with its unique character. The concept of flexible firm by Atkinson [31,32] provides possible answer.

Final question is regarding "How do professional workers relate to Society 5.0 goals especially in order to provide a human-centered world that is sustainable, vibrant and livable?". By its objective, it can be concluded that social sustainability is the core of Society 5.0. This objective can be achieved by integrating two previous theories and combining with Theory of Work Adjustment (TWA) that also known as Person-Environment Correspondence Theory (P-E-C Theory) by Dawis [33-35].

\subsection{Professional Worker}

The existence of knowledge workers is driven by the emergence of a knowledge-based economy. Drucker described knowledge workers as those who possess, utilize, and create valuable knowledge without precisely define the group nor give estimates of their numbers in the U. S. Economy $[28,29,36]$. Another most frequently cited definition of knowledge workers is comes from Davenport whom describes knowledge workers as workers who have a high level of knowledge, expertise and experience, and the main objectives of their work always involve the process of creating, distributing and applying knowledge [37,38]. The theory of productivity of knowledge workers by Drucker describe six aspects to indicate the productivity of knowledge workers [29,30,39-46], namely

1. The knowledge workers productivity depends on the demands of the assigned task. The duties of knowledge workers are oriented towards the utilization and creation of knowledge, 
2. Knowledge workers have flexibility or autonomy in carrying out their work,

3. One of the responsibilities of a knowledge worker is to always innovate,

4. Continuous learning and teaching is embedded in the knowledge workers work,

5. The quality of work and the quantity of work performed are equally important,

6. Knowledge workers should be treated as intellectual capital.

It can be seen that Government of Japan target for high quality human resource in Society 5.0 which is "human that think independently and create new values by combining various items while working with others" is closely related to six determinants of knowledge-worker and by proxy, professional worker.

\subsection{Flexible Firm}

How professional worker can contribute in organizational and environmental sustainability? Since one of the attributes of professional worker is autonomy, many scholars study the utilization of professional worker in flexible setting such as project networks [47-49]; interorganizational projects [50-52]; and temporary organizations [53-55]. Almost similar concept also proposed by Chesbrough [56] as 'Open Innovation' that using the input of outside expert to improve internal innovation processes.

The concept of the 'flexible firm' was originated from Atkinson [31,32] who identified the rising trend for firms to seek higher operational flexibility in response to market needs. Atkinson proposed three different forms of flexibility within an organization,

1. Functional flexibility, is a form of firm flexibility by utilizing knowledgeable and highly skilled to perform various tasks with different functions.

2. Numerical flexibility, is a form of firm flexibility that makes firm able to adjust the number of employees through various employment schemes.

3. Financial flexibility, is a form of firm flexibility that makes firm able to adjust the cost of labor in accordance with the supply and demand of workers within the company. 
Apart from these three forms of flexibility, Atkinson also outlines two dimensions in which flexibility can be applied,

1. Flexibility in employment, is flexibility dimension related to how the firm employ the workforce based on firm workload. Flexibility in employment achieved through implementing various employment schemes such as part-time, 'zero-hours' contracts and including independent professional worker that currently trending. Flexibility in employment can affect firm financial and numerical flexibility.

2. Flexibility in work, is flexibility dimension related to how the worker works in the firm. Some flexibility in work that currently trending such as flexi-time, flexible schedule, flexible places (i.e. working from home) and other flexible working arrangement.

\subsection{Theory of Work Adjustment}

Based on the literature review, most of social or human dimension antecedents leads to professional worker work engagement or professional worker job satisfaction. Early study of satisfaction comes from Theory of Work Adjustment (TWA) or also known as Person-Environment Correspondence Theory (P-E-C Theory) that developed by Dawis in 1964. The theory describes the correspondence between the worker and their job under two conditions: first is a relationship between abilities of the individual and the expectations of the employer. Secondly, it addresses the needs of the individual employee and the satisfaction of those needs by the current work environment in the organization [33-35].

The harmony between worker capabilities and employer or environment expectations will cause worker satisfaction and environment satisfactory. Consequently, any lack of harmony will influence the worker output or performance. Flexibility is observed in one's ability to handle lack of harmony between needs and job reinforcers, before moving forward to make an adjustment [34]. Lofquist and Dawis [34] argue that the flexibility of a worker or a work environment will determine the way worker will approach their work.

Dawis [35] insist that the theory of work adjustments determines level of performance when the capabilities of workers and the performance requirements are harmonized. Other study shows flexibility in work that allows workers to have more control and autonomy at work, will contributes to higher work engagement [10] that also leads to higher performance [57-59]. 


\subsection{Conceptual Framework}

By overlaying Drucker's knowledge-worker's productivity theory and Atkinson's flexible firm, there is opportunity for professional worker utilization can contribute to organizational and environmental sustainability. From environmental sustainability perspective, flexibility in work and employment of professional worker can reduce required built environment needed for centralized workplace. Moreover, less commuting for worker means less carbon footprint generated. From organizational perspective, by optimizing and seeking balance between functional, numerical and financial flexibility, organization can optimize costs, and ensures better allocation of resources for organization. Adding Dawis's theory of work adjustment will complement it with social sustainability perspective especially employee social health and enhancing employee well-being. Therefore, the utilization of professional worker as organization flexible resources in Society 5.0 can contribute to triple bottom line of sustainability [60] as shown in Figure 1.

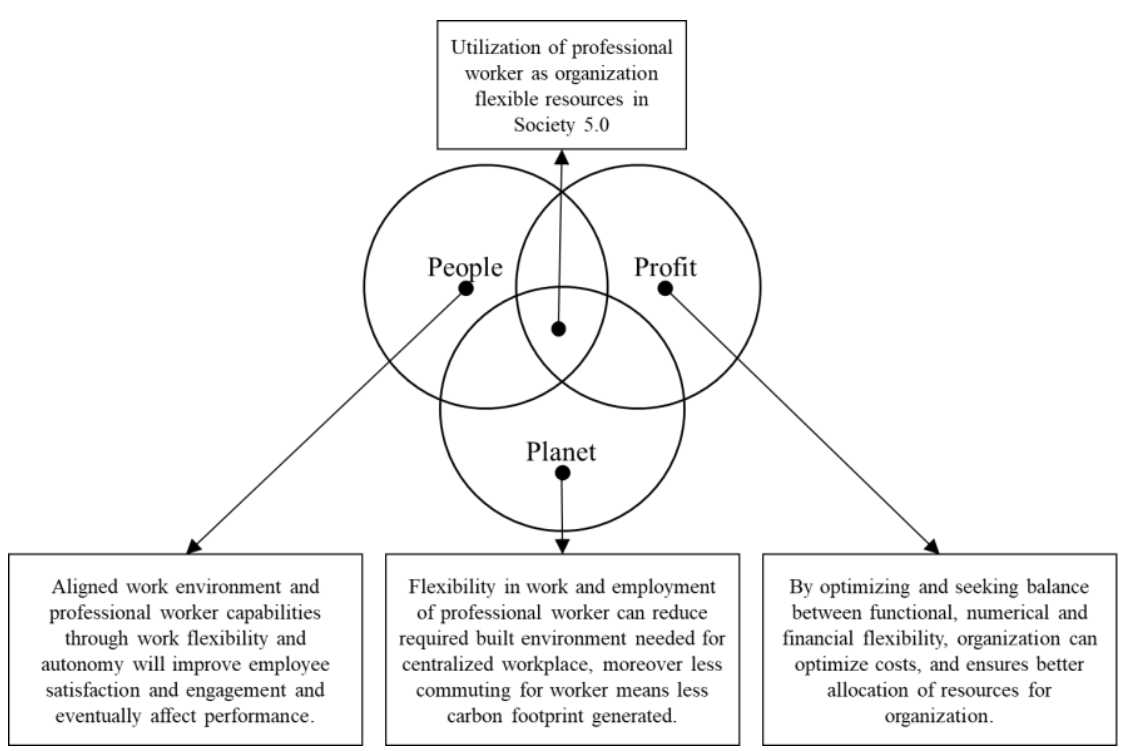

Figure 1. Professional Worker Contribution to Triple Bottom Line of Sustainability in Society 5.0.

However, there are challenges in being able to adapt the solutions. One reason is the concern that the utilization of professional workers and adding more flexibility in the firm will affect the work engagement of these professional workers and ultimately affect the professional workers performance. In order to answer the concern, this study attempt to develop 
necessery construct to support the developed conceptual framework without sacrificing work engagement and professional workers performance.

\section{Construct Development}

The construct development for the conceptual framework is based on the systematic literature review. The significant antecedents that have considered should be in place for professional worker in supporting Society 5.0 goals detailed in the following section.

\subsection{Result-Oriented Capabilities}

The key performance indicator for knowledge worker is how they can deliver the expected result based on their capability of creation, transfer and practical use of professional knowledge. Furthermore, Adriaensen [61] proposed that the greater the degree to which knowledge workers focus on the results they want to deliver, the more likely it is that their productivity will rise. In order to deliver the expected result, professional worker need certain set of capability. Previous research indicate some necessary capability such as prior work experience [62-64], prior occupational experience [62,64-67], excellent education $[40,68,69]$, communicating with other depending on the logic of a situation [42] , socially oriented work behaviors [70,71], cooperation $[38,72]$, interpersonal skill $[73,74]$, autonomy $[21,46,62]$, autonomous role in decision-making processes [75], problem solving [45], innovativeness [40,76,77], innovate continuously [30], creativity [30,62].

Previous research suggested that the most important capabilities of professional worker can be grouped into several categories namely Professional Expertise, Relational Capability, Operational Capability and Innovation Orientation. These capabilities grouped as Result-Oriented Capabilities and defined as "capabilities of professional worker that enable them to deliver the expected result".

\subsection{Sustainable Professional Development}

The need for continuous development of individual skill and knowledge becoming more critical in rapid changing global knowledge economy nowadays [78]. Knowledge workers have to continously learn how to lead, organize their own work and create their own careers $[29,30,43]$. Thus, professional worker should practice sustainable professional development. 
Professional development is defined as a consciously planned and thoughtful action by professionals worker to achieve, utilize and maintain knowledge, skills, and expertise [79]. It is a process of acquiring skills, knowledge, professional qualification and experience that help advance a professional worker's career. The main objective of professional development is to increase one's knowledge and skills. In addition to increasing knowledge, skills and competencies, professional development provides a competitive advantage, increases employability and earning potential, increases efficiency, and builds professional brand or credibility [79]. Professional development involves both formal and informal learning activities about their professional practice [80].

Since relevant skills change over time as mentioned by Sze-yeng \& Hussain [81] "Skills become obsolete over a couple of years due to the decreasing half-life of knowledge". Hence, the professional development must be sustainable. In this study, sustainable broadly refers to the durability in practice as used by Singh [82]. Therefore, the acquired knowledge, skills and competencies from sustainable professional development can be maintained and become the foundation in the career development of knowledge workers.

Furthermore, to retained and maintained the acquired knowledge, skills and competencies, managing personal knowledge is strategically important. In 1999, Frand and Hixon introduced the term "personal knowledge management" (PKM) [83]. The concept has evolved and currently inlcludes organising information, making sense of information, negotiating meaning, creating new ideas, developing networks, collaborating, interacting and sharing of knowledge in individual level [83,84]. PKM focuses on the individual needs and objectives of learning, socialising, and completing work tasks effectively [85].

Professional worker can achieve sustainable professional development by developing their own competence [61,78], and by implementing personal knowledge management. Those two aspects highly correlates with professional worker's own continuous learning and teaching [79,81].

\subsection{IT Competence}

Since Society 5.0 is designed to leveraging technology from Industry 4.0 to its fullest and utilizing cyberspace as well as physical space in daily work [13], IT literacy become a must have core competence for professional worker in Society 5.0. Professional worker's IT competence in this study is defined as the ability of professional worker to efficiently and effectively contribute to organizational objectives with the use of IT [86]. 
IT usage provides much flexibility and convenience for professional worker, for example IT facilitate professional worker to increase their connectivity and enhancing work autonomy [87]. Thus, this study hypotized that IT is likely to become an enabler for professional worker to connect especialy with their colleagues and supervisors at any time. The ease of connectivity would increase level of work engagement and lower level of mental exhaustion $[88,89]$.

\subsection{Work Engagement}

Work engagement refers to "a positive, fulfilling, work-related state of mind that is characterized by vigor, dedication, and absorption" [9]. Published scientific research results on engagement indicate that engagement is associated with lower turnover [8,10,90], positive job attitudes [5,6,10,90], and higher levels of performance especially at the individual and unit levels $[5,6,10,90]$. Professional worker characteristics such as result-oriented capabilities, IT competence and sustainable professional development allow professional workers to be able to deliver work results in accordance with the expected results. According to Lofquist and Dawis [34], the two main indicators of successful work relationships are individual satisfaction and work environment satisfaction. Work environment satisfactory is achieved when individual expertise is in accordance with work requirements and individual satisfaction occurs when a work environment reinforces individual values. This satisfaction will increase the work engagement of professional workers. Thus this study hypotize that professional worker characteristics and work engagement is positively related.

\subsection{Profesional Worker Performance}

Many empirical research has proven the presence of the relation between characteristics of professional worker and performance [29,43,46,62,65]. Systematic literature review by Ramírez and Nembhard [46] examined more than 60 years of literature to find the generally accepted indicators for measuring knowledge worker performance. Knowledge worker performance indicator arranged by the most frequent use are quantity of the job done, cost and profitability, timeliness, autonomy, efficiency, quality, effectiveness, customer satisfaction, creativity or innovative behavior, project success, responsibility of and importance to knowledge work, knowledge worker's perception of productivity and absenteeism. Most of previous studies on 
average used two to three dimensions depending on the research objective [46].

Since this study grouped job autonomy as one of the components of professional characteristics. Therefore, this research will focus on the quality, timeliness, efficiency and effectiveness of the professional worker's tasks at the workplace as measurement for professional worker performance. Timeliness refers to how professional worker comply with deadlines. Likewise, work or task efficiency measures doing things right so that knowledge-based tasks are completed, meeting all the standards of time and quality [46]. The work efficiency and timeliness dimensions measure the quantity of the output (efficiency) while meeting quality of output (effectiveness) standards [46].

Further study strives to compare the direct and indirect effect of the independent variable and investigate the contribution of work engagement since it is important to social sustainability in Society 5.0. Therefore, the conceptual model of this study as shows in Figure 2.

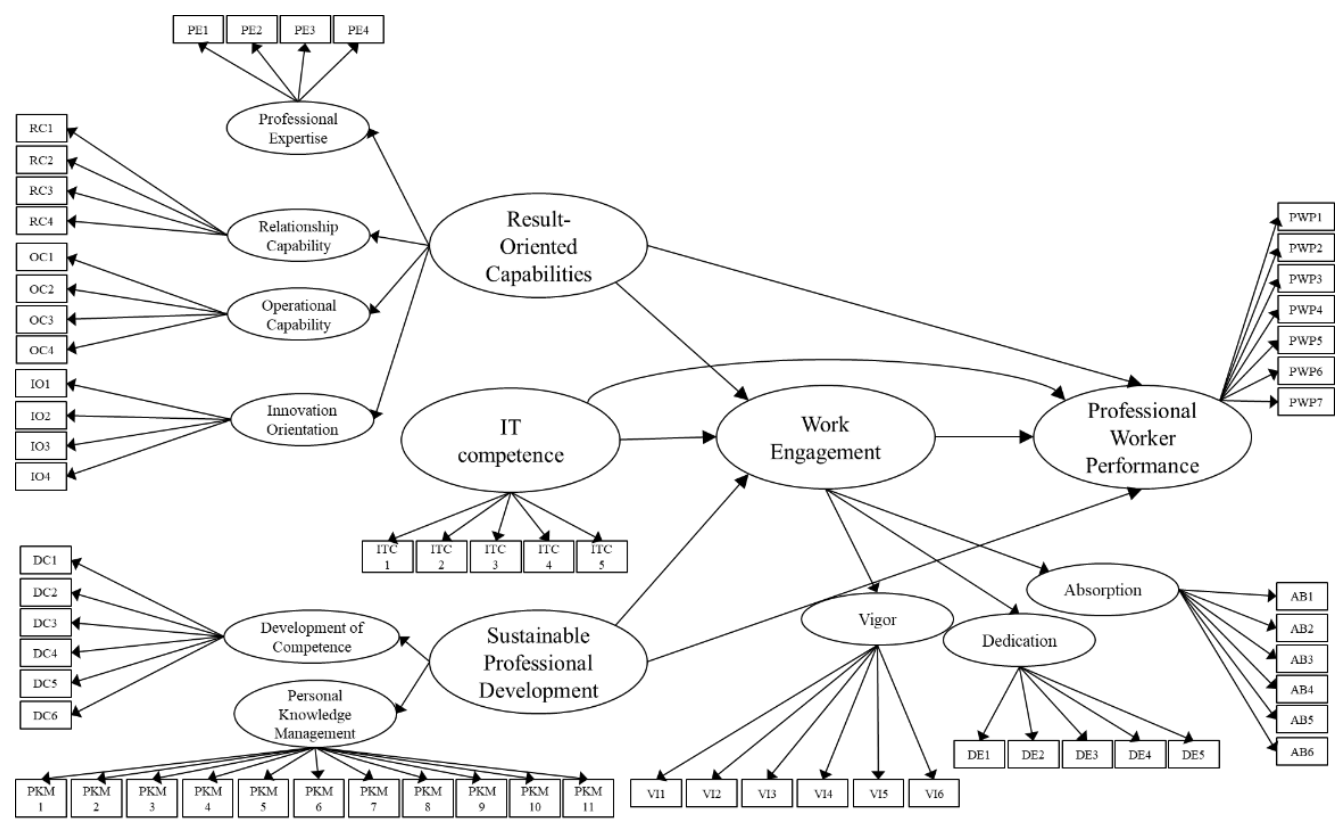

Figure 2. Conceptual Research Model 


\section{Results and Discussion}

Conceptual framework development through literature review with theory synthesis approach evidenced that optimal utilization of professional worker could increase work engagement and potentially contribute to organizational and environmental sustainability in Society 5.0. Previous study linked workers participation to organizational performance [91,92] such as firm competitive performance and firm financial success. Study about professional worker innovative work behavior found that there is significant relationship between pro-innovation organizational climates with the innovative work behavior of professional workers [93]. Moreover, another study linked between social, economic and environment dimension by showing that office sustainable design not only affected social sustainability such as work engagement but also occupant performance and firm financial impact [94]. Therefore, in Society 5.0 era, the capability of organizations to collaborate with professional worker whether as internal or external resource and to exploit organizational flexibility become more critical for the organization sustainability.

This study also provides an integrated perspective, centered on professional worker distinctive characteristics that influences positively on work engagement and professional worker performance. The construct developed in conceptual research model strive to provide foundation for organization in order to achieve organizational sustainability through professional worker performance improvement.

\section{Conclusion}

This study develops a conceptual framework that linked Result-Oriented Capabilities, IT Competence, Sustainable Professional Development, Work Engagement and examines their effect on Professional Worker Performance. This study conducted literature review with theory synthesis approach and integrating between Drucker's knowledge-worker's productivity theory, Atkinson's Flexible Firm and Dawis's theory of work adjustment (PEC Theory) to propose and examine the antecedents and consequences of Professional Worker Performance in Society 5.0. The study diverges from prior studies on professional worker by examining professional worker inherent characteristics in leveraging work engagement to enable professional worker to achieve higher job performance, thereby expanding the cumulative knowledge in this research topic. The conceptualization and investigation of the independent and combined effect of Result-Oriented Capabilities, IT 
Competence, Sustainable Professional Development, Work Engagement and Professional Worker Performance highlight the importance of complementarities between antecedents and set standing for future research. 


\section{References}

1. Florea L, Cheung YH, Herndon NC. For all good reasons: Role of values in organizational sustainability. J Bus Ethics. 2013;114(3):393-408.

2. Eccles RG, Ioannou I, Serafeim G. The impact of corporate sustainability on organizational processes and performance. Manage Sci. 2014;60(11):2835-57.

3. Wang S, Noe RA. Knowledge sharing: A review and directions for future research. Hum Resour Manag Rev. 2010;20(2):115-31.

4. Aninkan DO, Oyewole AA. The influence of individual and organizational factors on employee engagement. Int J Dev Sustain. 2014;3(6):1381-92.

5. Kim W, Khan GF, Wood J, Mahmood MT. Employee engagement for sustainable organizations: Keyword analysis using social network analysis and burst detection approach. Sustainability. 2016;8(7):631.

6. Spreitzer G, Porath CL, Gibson CB. Toward human sustainability: How to enable more thriving at work. Organ Dyn. 2012;41(2):155-62.

7. Kiron D, Kruschwitz N, Haanaes K, Velken IVS. Sustainability nears a tipping point. MIT sloan Manag Rev. 2012;53(2):69.

8. Schaufeli WB, Taris TW, Van Rhenen W. Workaholism, burnout, and work engagement: Three of a kind or three different kinds of employee well-being? Appl Psychol. 2008;57(2):173-203.

9. Schaufeli WB, Salanova M, González-Romá V, Bakker AB. The measurement of engagement and burnout: A two sample confirmatory factor analytic approach. J Happiness Stud. 2002;3(1):71-92.

10. Bailey C, Madden A, Alfes K, Fletcher L. The meaning, antecedents and outcomes of employee engagement: A narrative synthesis. Int J Manag Rev. 2017;19(1):31-53.

11. Government of Japan. The 5th Science and Technology Basic Plan [Internet]. 2016. Available from: https://www8.cao.go.jp/cstp/english/basic/5thbasicplan.pdf

12. Government of Japan. Outline of the Fifth Science and Technology Basic Plan [Internet]. 2016. Available from: https://www8.cao.go.jp/cstp/english/basic/5thbasicplan_outline.pdf

13. Federation KB. Toward realization of the New Economy and Society-Reform of the Economy and Society by the Deepening of "Society 5.0." Keidanren, Tokyo; 2016.

14. Gladden ME. Who will be the members of Society 5.0? Towards an anthropology of technologically posthumanized future societies. Soc Sci. 2019;8(5):148.

15. Medina-Borja A. Smart human-centered service systems of the future. Cent Res Dev Strateg Japan Sci Technol Agency, Futur Serv Soc Syst Soc. 2017;5.

16. Harayama Y. Society 5.0: aiming for a new human-centered society. Hitachi Rev. 2017;66(6):556-7.

17. Serpa S, Ferreira C. Society 5.0 and Social Development: Contributions to a Discussion. 2018; 
18. Ekstedt E. Form of employment in a project-intensive economy. Am J Ind Med. 1999;36(S1):11-4.

19. Ekstedt E, Lundin RA, Söderholm A, Wirdenius H. Neo-Industrial Organising: Renewal by Action and Knowledge Formation in a Project-intensive Economy. London: Routledge; 1999. 256 p.

20. Ekstedt E. Project work, a challenge to traditional work life institutions. Int J Manag Proj Bus. 2019;12:267-81.

21. Surawski B. Who is a "knowledge worker"--clarifying the meaning of the term through comparison with synonymous and associated terms. Management [Internet]. 2019;23(1):105-33. Available from: https://content.sciendo.com/view/journals/manment/23/1/articlep105.xml?language $=$ en

22. Jaakkola E. Designing conceptual articles: four approaches. AMS Rev. 2020;1-9.

23. MacInnis DJ. A framework for conceptual contributions in marketing. J Mark. 2011;75(4):136-54.

24. Nonaka I. A dynamic theory of organizational knowledge creation. Organ Sci. 1994;5(1):14-37.

25. Nonaka I, Takeuchi H. The knowledge-creating company: How Japanese companies create the dynamics of innovation. Oxford university press; 1995.

26. Polanyi M. Personal Knowledge: Towards a Post-Critical Philosophy. Chicago; 1958.

27. Nye MJ. Michael Polanyi: Science as personal knowledge and social practice. Angew Chemie Int Ed. 2017;56(13):3426-33.

28. Drucker PF. Management and the professional employee. Harv Bus Rev. 1952;30(3):84-90.

29. Drucker PF. Knowledge-worker productivity: The biggest challenge. Calif Manage Rev. 1999;41(2):79-94.

30. Turriago-Hoyos A, Thoene U, Arjoon S. Knowledge workers and virtues in Peter Drucker's management theory. SAGE Open. 2016;6(1):2158244016639631.

31. Atkinson J. Manpower strategies for flexible organisations. Pers Manag J Inst Pers Manag. 1984;16(8):28-31.

32. Atkinson J. The flexible firm and the shape of jobs to come. Labour Mark issues. 1984;5:26-9.

33. Dawis R V. The theory of work adjustment and person-environment-correspondence counseling. Career choice Dev. 1996;3:75-120.

34. Lofquist LH, Dawis R V. Essentials of person-environment-correspondence counseling. U of Minnesota Press; 1991.

35. Dawis R V. Person-environment-correspondence theory. Career choice Dev. 2002;4:427-64.

36. Drucker PF. Landmarks of tomorrow: A report on the new. Transaction Publishers; 
2011. $270 \mathrm{p}$.

37. Davenport TH, Prusak L. Working knowledge: How organizations manage what they know. Harvard Business Press; 1998.

38. Davenport TH. Thinking for a living: how to get better performances and results from knowledge workers. Harvard Business Press; 2005. 240 p.

39. Drucker P. The Landmarks of Tomorrow. In New York: Heinemann; 1959. p. 13-40.

40. Lamond D, Huang Y-C, Wu Y-CJ. Intellectual capital and knowledge productivity: the Taiwan biotech industry. Manag Decis. 2010;48(4):580-99.

41. Iazzolino G, Laise D, Gabriele R. Knowledge-based strategies and sustainability: a framework and a case study application. Meas Bus Excell. 2017;

42. Palvalin M, van der Voordt T, Jylhä T. The impact of workplaces and selfmanagement practices on the productivity of knowledge workers. J Facil Manag. 2017 ;

43. Kianto A, Shujahat M, Hussain S, Nawaz F, Ali M. The impact of knowledge management on knowledge worker productivity. Balt J Manag. 2019;

44. Joo B-KB, Park JG, Lim T. Structural determinants of psychological well-being for knowledge workers in South Korea. Pers Rev. 2016;

45. Moussa M, Bright M, Varua ME. Investigating knowledge workers' productivity using work design theory. Int J Product Perform Manag. 2017;

46. Ramírez YW, Nembhard DA. Measuring knowledge worker productivity: A taxonomy. J Intellect Cap. 2004;5(4):602-28.

47. DeFillippi R, Sydow J. Project networks: Governance choices and paradoxical tensions. Proj Manag J. 2016;47(5):6-17.

48. Gemünden HG. Project networks - an important—but still under-researched topic in project management research. Proj Manag J. 2016;47(5):3-5.

49. Manning S. The rise of project network organizations: Building core teams and flexible partner pools for interorganizational projects. Res Policy [Internet]. 2017 Oct 1 [cited 2018 Jul 23];46(8):1399-415. Available from: https://www.sciencedirect.com/science/article/pii/S0048733317301026

50. Williams T. Cooperation by design: structure and cooperation in interorganizational networks. J Bus Res. 2005;58(2):223-31.

51. Sydow J, Braun T. Projects as temporary organizations: An agenda for further theorizing the interorganizational dimension. Int J Proj Manag. 2018;36(1):4-11.

52. Zerjav V, Edkins A, Davies A. Project capabilities for operational outcomes in interorganisational settings: The case of London Heathrow Terminal 2. Int J Proj Manag. 2018;36(3):444-59.

53. Dille T, Söderlund J, Clegg S. Temporal conditioning and the dynamics of interinstitutional projects. Int J Proj Manag. 2018;36(5):673-86.

54. Bakker RM, DeFillippi RJ, Schwab A, Sydow J. Temporary organizing: Promises, 
processes, problems. Organ Stud. 2016;37(12):1703-19.

55. Burke CM, Morley MJ. On temporary organizations: A review, synthesis and research agenda. Hum relations. 2016;69(6):1235-58.

56. Chesbrough HW. Open innovation: The new imperative for creating and profiting from technology. Harvard Business Press; 2003.

57. Rich BL, Lepine JA, Crawford ER. Job Engagement: Antecedents and Effects on Job Performance. Acad Manag J [Internet]. 2010 Jun [cited 2018 Jul 23];53(3):617-35. Available from: http://journals.aom.org/doi/10.5465/amj.2010.51468988

58. Anitha J. Determinants of employee engagement and their impact on employee performance. Int J Product Perform Manag. 2014;

59. Salanova M, Agut S, Peiró JM. Linking Organizational Resources and Work Engagement to Employee Performance and Customer Loyalty: The Mediation of Service Climate. J Appl Psychol [Internet]. 2005 [cited 2018 Jul 23];90(6):1217-27. Available from: http://doi.apa.org/getdoi.cfm?doi=10.1037/0021-9010.90.6.1217

60. Elkington J. Partnerships from cannibals with forks: The triple bottom line of 21stcentury business. Environ Qual Manag. 1998;8(1):37-51.

61. Adriaenssen DJ, Johannessen DA, Johannessen J-A. Knowledge management and performance: developing a theoretical approach to knowledge workers' productivity, and practical tools for managers. Probl Perspect Manag. 2016;(14, Iss. 3 (contin. 3)):667-76.

62. Dokko G, Wilk SL, Rothbard NP. Unpacking prior experience: How career history affects job performance. Organ Sci. 2009;20(1):51-68.

63. Almeida P, Dokko G, Rosenkopf L. Startup size and the mechanisms of external learning: increasing opportunity and decreasing ability? Res Policy. 2003;32(2):30115 .

64. McDaniel MA, Schmidt FL, Hunter JE. Job experience correlates of job performance. J Appl Psychol. 1988;73(2):327.

65. Schmidt FL, Hunter JE, Outerbridge AN. Impact of job experience and ability on job knowledge, work sample performance, and supervisory ratings of job performance. $\mathrm{J}$ Appl Psychol. 1986;71(3):432.

66. Segal-Horn S, Dean A. Delivering 'effortless experience' across borders: Managing internal consistency in professional service firms. J World Bus [Internet]. 2009 Jan 1 [cited $2018 \mathrm{Jul} 2$ ];44(1):41-50. Available from: https://www.sciencedirect.com/science/article/pii/S1090951608000163

67. Borman WC, Hanson MA, Oppler SH, Pulakos ED, White LA. Role of early supervisory experience in supervisor performance. J Appl Psychol. 1993;78(3):443.

68. Örnek AŞ, Ayas S. The Relationship between Intellectual Capital, Innovative Work Behavior and Business Performance Reflection. Procedia - Soc Behav Sci [Internet]. 2015 Jul 3 [cited 2018 Jul 23];195:1387-95. Available from: https://www.sciencedirect.com/science/article/pii/S1877042815039129 
69. Erickson GS, Rothberg HN. Knowledge assets in services across industries and across time. Investig Eur Dir y Econ la Empres. 2015;21(2):58-64.

70. Dierdorff EC, Morgeson FP. Getting what the occupation gives: Exploring multilevel links between work design and occupational values. Pers Psychol. 2013;66(3):687721.

71. Sousa MC de, Dierendonck D van. Knowledge workers, servant leadership and the search for meaning in knowledge-driven organizations. Horizon-The Strateg Plan Resour Educ Prof. 2010;18(3):230-9.

72. Bessant J, Tidd J. Managing innovation: integrating technological, market and organizational change. Wiley; 2013.

73. Swart J, Henneberg SC. Dynamic knowledge nets--the 3C model: exploratory findings and conceptualisation of entrepreneurial knowledge constellations. J Knowl Manag. 2007;

74. Swart J. HRM and knowledge workers. In: The Oxford handbook of human resource management. 2007.

75. Segarra-Oña M, Peiró-Signes Á, Mondéjar-Jiménez J. Twisting the twist: how manufacturing \&amp; knowledge-intensive firms excel over manufacturing \&amp; operational and all service sectors in their eco-innovative orientation. J Clean Prod [Internet]. 2016 Dec 1 [cited 2018 Jul 6];138:19-27. Available from: https://www.sciencedirect.com/science/article/pii/S0959652616000263

76. Shujahat M, Sousa MJ, Hussain S, Nawaz F, Wang M, Umer M. Translating the impact of knowledge management processes into knowledge-based innovation: The neglected and mediating role of knowledge-worker productivity. J Bus Res. 2019;94:442-50.

77. Yuan F, Woodman RW. Innovative behavior in the workplace: The role of performance and image outcome expectations. Acad Manag J. 2010;53(2):323-42.

78. Stiglitz JE, Greenwald BC. Creating a learning society: A new approach to growth, development, and social progress. Columbia University Press; 2014.

79. Havea PH, Mohanty M. Professional development and sustainable development goals. In Springer Nature; 2020.

80. Knapp MS. Chapter 4: Professional development as a policy pathway. Rev Res Educ. 2003;27(1):109-57.

81. Sze-Yeng F, Hussain RMR. Self-directed learning in a socioconstructivist learning environment. Procedia-Social Behav Sci. 2010;9:1913-7.

82. Singh K, Schrape J, Kelly J. Emerging strategies for a sustainable approach to professional development. In: ascilite. 2012.

83. Frand J, Hixon C. Personal knowledge management: Who, what, why, when, where, how?. 1999. URL http//www anderson ucla edu/faculty/jason frand/researcher/speeches/PKM htm retrieved March. 2007;

84. Wright K. Personal knowledge management: supporting individual knowledge worker 
performance. Knowl Manag Res Pract. 2005;3(3):156-65.

85. Razmerita L, Kirchner K, Sudzina F. Personal knowledge management. Online Inf Rev. 2009;

86. Lepak DP, Snell SA. Examining the Human Resource Architecture: The Relationships Among Human Capital, Employment, and Human Resource Configurations. J Manage [Internet]. 2002 Aug 30 [cited 2018 Jul 23];28(4):517-43. Available from: http://journals.sagepub.com/doi/10.1177/014920630202800403

87. Miyata K, Boase J, Wellman B, Ikeda K. The mobile-izing Japanese: connecting to the internet by PC and webphone in Yamanashi. Pers portable, Pedestr Mob phones Japanese life. 2005;1.

88. Demerouti E, Mostert K, Bakker AB. Burnout and work engagement: a thorough investigation of the independency of both constructs. J Occup Health Psychol. 2010;15(3):209.

89. Goldberg LS, Grandey AA. Display rules versus display autonomy: emotion regulation, emotional exhaustion, and task performance in a call center simulation. J Occup Health Psychol. 2007;12(3):301.

90. Macey WH, Schneider B. The meaning of employee engagement. Ind Organ Psychol. 2008;1(1):3-30.

91. Bakotić D, Buble M. Relationship Between Knowledge Workers' Participation and Organizational Performance. Econ Res Istraživanja [Internet]. 2011;24(3):115-30. Available from: https://doi.org/10.1080/1331677X.2011.11517471

92. Bouncken RB, Kraus S. Innovation in knowledge-intensive industries: The doubleedged sword of coopetition. J Bus Res. 2013;66(10):2060-70.

93. Kheng YK, Mahmood R. The Relationship between Pro-Innovation Organizational Climate, Leader-Member Exchange and Innovative Work Behavior: A Study among the Knowledge Workers of the Knowledge Intensive Business Services in Malaysia. In 2013 .

94. Feige A, Wallbaum H, Janser M, Windlinger L. Impact of sustainable office buildings on occupant's comfort and productivity. J Corp Real Estate. 2013;15. 